[Article]

\title{
光还原催化剂 $\mathrm{Pt} / \mathrm{TiO}_{2}$ 富氢条件下 $\mathrm{CO}$ 优先氧化反应
}

\author{
王 芳* 王彩红 刘国霞 \\ (滨州学院化学与化工系, 山东滨州 256603)
}

\begin{abstract}
摘要：用光还原法来提高富氢条件下 $\mathrm{CO}$ 优先氧化 (PROX) 催化活性和 $\mathrm{CO}_{2}$ 选择性, 分别对有无氢气时 $\mathrm{CO}$ 氧 化反应参数进行了详尽研究. X射线光电子能谱(XPS)表征结果显示, 在光还原催化剂表面产生了部分氧空穴, 可为化学吸附 $\mathrm{H}$ 提供活性中心. 针对光还原 $\mathrm{Pt} / \mathrm{TiO} \mathrm{O}_{2}$ 催化剂上 $\mathrm{CO}$ 优先氧化反应提出了一种可能的双功能反应 机理.
\end{abstract}

关键词：CO优先氧化; Pt 催化剂; 光还原; 浸渍 中图分类号: 0643

\section{Preferential Oxidation of $\mathrm{CO}$ over Photoreduced $\mathrm{Pt} / \mathrm{TiO}{ }_{2}$ Catalysts in $\mathrm{H}_{2}$-Rich Stream}

\author{
WANG Fang* WANG Cai-Hong LIU Guo-Xia \\ (Department of Chemistry \& Chemical Engineering, Binzhou University, Binzhou 256603, Shandong Province, P. R. China)
}

\begin{abstract}
The optimum reaction parameters for $\mathrm{CO}$ oxidation in the presence and absence of $\mathrm{H}_{2}$ have been investigated by photoreduction method to enhance the catalytic activity and selectivity of $\mathrm{CO}_{2}$ for $\mathrm{CO}$ preferential oxidation (PROX) in $\mathrm{H}_{2}$-rich stream in detail. X-ray photoelectron spectroscoopy (XPS) results showed that part oxygen vacancies produced on the surface of photoreduced catalysts, which maybe the activity site for the chemisorbed $\mathrm{H}$. Therefore, a possible bi-function reaction mechanism for $\mathrm{CO}$ preferential oxidation over the photoreduced $\mathrm{P} / / \mathrm{TiO}_{2}$ catalyst has been proposed.
\end{abstract}

Key Words: CO preferential oxidation; Pt catalyst; Photoreduction; Impregnation

\section{Introduction}

Currently, the CO oxidation in the absence and presence of $\mathrm{H}_{2}$ has attracted extensive attention because of its potential application in indoor or cabin air cleanup and in the purification of hydrogen streams used in proton exchange membrane (PEM) fuel cells. ${ }^{1,2}$ Considerable efforts have been devoted to design the suitable catalysts for the competitive oxidation of $\mathrm{CO}$ in the presence of hydrogen. Supported noble metals, such as $\mathrm{Au},{ }^{3,4} \mathrm{Pt},{ }^{5-10} \mathrm{Pd},{ }^{11-13}$ and $\mathrm{Rh},{ }^{14}$ were found applicable for the PROX reaction. Platinum catalysts are by far the most extensively studied catalysts owing to their superior performance in photocatalytic and thermal $\mathrm{CO}$ oxidation. Nevertheless, the most commonly used $\mathrm{Pt} / \mathrm{TiO}_{2}$ catalysts prepared by impregnation method are unsuitable for the reaction of $\mathrm{CO}$ preferential oxidation since they require high operation temperature in the range of $150-200{ }^{\circ} \mathrm{C}$. In the meantime, significant $\mathrm{H}_{2}$ consumption can be observed in the temperature range to work effectively. Furthermore, the impregnated $\mathrm{Pt} / \mathrm{TiO}_{2}$ catalyst used to be pretreated by oxidation or reduction under an appropriate temperature prior to the catalytic activity tests. ${ }^{15-18}$ This gives an incentive for the development of a highly active and selective catalyst for $\mathrm{CO}$ preferential oxidation.

By comparison, the photoreduction method exhibits many advantages, such as simple operation and environment-friendly

Received: August 11, 2011; Revised: November 2, 2011; Published on Web: November 24, 2011.

"Corresponding author. Email: wangfangosso@yahoo.cn; Tel: +86-18763029669.

The project was supported by the Research Fund of Binzhou University, China (2010Y06).

滨州学院科研基金(2010Y06)资助项目

(C) Editorial office of Acta Physico-Chimica Sinica 
etc. In this study, we mainly focus on the preparation of $\mathrm{Pt} /$ $\mathrm{TiO}_{2}$ catalysts by a photoreduction method. The optimum reaction parameters for $\mathrm{CO}$ oxidation in the presence and absence of $\mathrm{H}_{2}$ have been investigated in detail. Based on the data of catalytic activity tests and the characterization of catalysts, a possible reaction mechanism for the PROX reaction over the photoreduced $\mathrm{Pt} / \mathrm{TiO}_{2}$ catalyst has been proposed.

\section{Experimental}

\subsection{Catalyst preparation}

Degussa $\mathrm{P} 25 \mathrm{TiO}_{2}$ powder (Degussa, 70\%-30\% anatase) was used as a support. Before deposition, raw $\mathrm{TiO}_{2}$ was pretreated at $773 \mathrm{~K}$ for $4 \mathrm{~h}$ in air to stabilize its surface area and the anatase crystal form. Platinum was directly photodeposited on $\mathrm{TiO}_{2}$ in an aqueous solution of chloroplatinic acid $(1 \mathrm{mmol}$. $\left.\mathrm{L}^{-1}\right)$ and methanol $\left(0.1 \mathrm{~mol} \cdot \mathrm{L}^{-1}\right)$ under UV illumination $(250$ $\mathrm{W}$ medium-pressure mercury lamp). The samples were dried in air at $120^{\circ} \mathrm{C}$ for $12 \mathrm{~h}$ and had no thermal treatment anymore. The theoretical mass loading amount was $1.5 \%(w)$. In order to compare with the photoreduced $\mathrm{Pt} / \mathrm{TiO}_{2}$ catalysts, the impregnated catalyst was reduced in $\mathrm{H}_{2}$ stream at $300{ }^{\circ} \mathrm{C}$ for $1 \mathrm{~h}$ prior to the catalytic activity tests. We denoted the $\mathrm{Pt} / \mathrm{TiO}_{2}$ catalysts photoreduced for 12, 24, and $36 \mathrm{~h}$ as $\mathrm{Pt} / \mathrm{TiO}_{2}(\mathrm{PR} 12), \mathrm{Pt} / \mathrm{TiO}_{2}$ (PR24) and $\mathrm{Pt} / \mathrm{TiO}_{2}(\mathrm{PR} 36)$, respectively. And the impregnated one was denoted as $\mathrm{Pt} / \mathrm{TiO}_{2}$ (IM).

\subsection{Characterization of catalysts}

$\mathrm{X}$-ray diffraction (XRD) patterns of the samples were recorded on a Rigaku D/MAX-RB X-ray diffractometer with a $\mathrm{Cu} K_{\alpha}$ target operated at $50 \mathrm{kV}$ and $40 \mathrm{~mA}$ with a scanning speed of $0.5\left(^{\circ}\right) \cdot \mathrm{min}^{-1}$ and a scanning angle $(2 \theta)$ range of $10^{\circ}-90^{\circ}$. Chemical states of the Pt species on the catalyst surface were investigated by X-ray photoelectron spectroscopy (XPS) on a VG ESCALAB 210 Electron Spectrometer $\left(\mathrm{Mg} K_{\alpha}\right.$ radiation; $h v=1253.6 \mathrm{eV})$.

\subsection{Activity measurement}

Catalytic test was carried out at atmospheric pressure in a fixed bed continuous flow quartz reactor (inside diameter is $8 \mathrm{~mm}$ ), consisting of a flow controller unit, a reactor unit, and an analysis unit. A schematic diagram of the experimental system is shown in Fig.1. Typically, the temperature increased from 80 to $300{ }^{\circ} \mathrm{C}$ at a $5{ }^{\circ} \mathrm{C}$ increment, and a sample was taken for analysis after stabilizing for $30 \mathrm{~min}$ at each investigated temperature. Then $0.1 \mathrm{~g}$ catalyst diluted with equal amount of quartz was used in each run. Prior to the experiment, the impregnated catalyst was reduced in situ at $300{ }^{\circ} \mathrm{C}$ (heating rate: $10{ }^{\circ} \mathrm{C} \cdot \mathrm{min}^{-1}$ ) for $3 \mathrm{~h}$ with a $50 \%$ (volume fraction) $\mathrm{H}_{2} / \mathrm{N}_{2}$ mixture (flow rate: $60 \mathrm{~mL} \cdot \mathrm{min}^{-1}$ ). The feed gas consisted of $2.5 \%$ $\mathrm{CO}$ and $20 \% \mathrm{O}_{2}$ in $\mathrm{N}_{2}$ balance. In the process of PROX, a gas mixture containing $50 \% \mathrm{H}_{2}, 1 \% \mathrm{CO}$, and $2 \% \mathrm{O}_{2}$ in $\mathrm{N}_{2}$ was fed at the flow rate of $30 \mathrm{~mL} \cdot \mathrm{min}^{-1}$. The gas phase effluents were analyzed on-line chromatographs equipped with thermal conductivity detector (TCD). At the end of the catalytic tests, the catalyst was cooled under an $\mathrm{N}_{2}$ stream and stored for characterizations. The catalytic activities were defined in terms of conversion of $\mathrm{CO}(\eta)$, conversion of $\mathrm{O}_{2}$, and selectivity to $\mathrm{CO}_{2}$ $(S)$, which were denoted as $\eta_{\mathrm{CO}}, \eta_{\mathrm{O}_{2}}$ and $S_{\mathrm{CO}_{2}}$, respectively, and were calculated according to the following equations:

$$
\begin{aligned}
& \eta_{\mathrm{CO}}=\left\{\left([\mathrm{CO}]_{\text {in }}-[\mathrm{CO}]_{\text {out }} /[\mathrm{CO}]_{\text {in }}\right\} \times 100 \%\right. \\
& \eta_{\mathrm{O}_{2}}=\left\{\left(\left[\mathrm{O}_{2}\right]_{\text {in }}-\left[\mathrm{O}_{2}\right]_{\text {out }}\right) /\left[\mathrm{O}_{2}\right]_{\text {in }}\right\} \times 100 \% \\
& S_{\mathrm{CO}_{2}}=\left\{0.5 \times\left[\mathrm{CO}_{2}\right] /\left([\mathrm{CO}]_{\text {in }}-[\mathrm{CO}]_{\text {out }}\right)\right\} \times 100 \%
\end{aligned}
$$

\section{Results and discussion \\ 3.1 XRD analysis}

XRD patterns of various $\mathrm{Pt} / \mathrm{TiO}_{2}$ catalysts were shown in Fig.2. No obvious crystallite formation of the Pt species could be found in the XRD patterns of $\mathrm{Pt} / \mathrm{TiO}_{2}(\mathrm{PR} 12)$ and $\mathrm{Pt} / \mathrm{TiO}_{2}$

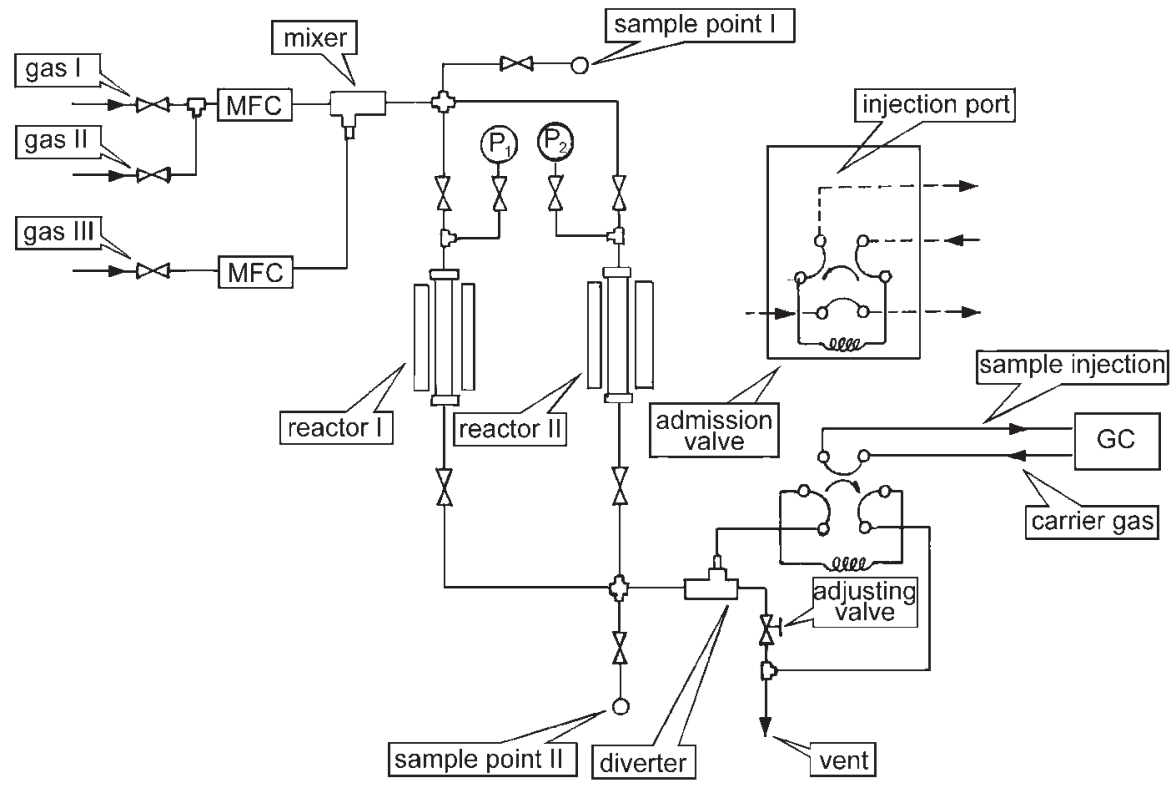

Fig.1 Diagram of apparatus for the test of catalytic activity 


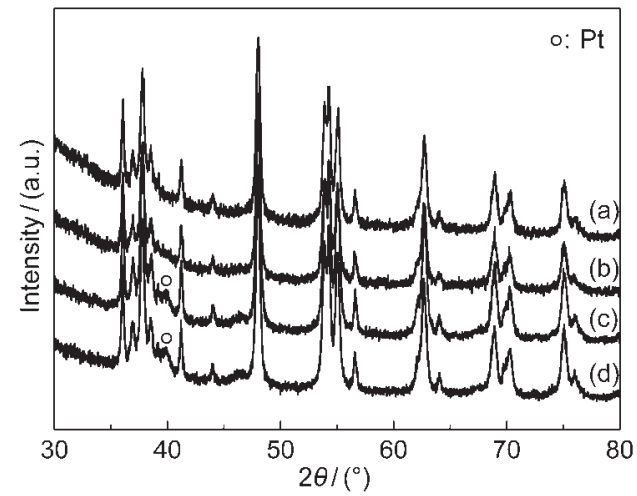

Fig.2 XRD patterns of various catalysts

(a) $\mathrm{Pt} / \mathrm{TiO}_{2}$ (PR12), (b) $\mathrm{Pt} / \mathrm{TiO}_{2}$ (PR24), (c) $\mathrm{Pt} / \mathrm{TiO}_{2}$ (PR36), (d) $\mathrm{Pt} / \mathrm{TiO}_{2}$ (IM)

(PR24) catalysts, which indicated that the low metal content might lead to a high dispersion of $\mathrm{Pt}$ and, therefore, that the $\mathrm{Pt}$ particles were too small to be detected by XRD analysis. However, only a broader diffraction peak of Pt appeared at $39.68^{\circ}$ for $\mathrm{Pt} / \mathrm{TiO}_{2}(\mathrm{PR} 36)$ and $\mathrm{Pt} / \mathrm{TiO}_{2}$ (IM) catalysts, which could be attributed to $\mathrm{Pt}$ (111). ${ }^{10}$ Therefore, the average crystallite sizes of Pt particles could be calculated by applying the Scherrer equation on the $\mathrm{Pt}$ (111) diffraction peaks. The calculated average crystallite sizes of $\mathrm{Pt}$ particles in $\mathrm{Pt} / \mathrm{TiO}_{2}$ (PR36) and $\mathrm{Pt} /$ $\mathrm{TiO}_{2}$ (IM) samples were 16 and $10 \mathrm{~nm}$, respectively. According to previous report, ${ }^{10}$ the concentrations of chlorine ions could be decreased by photoreduction, resulted in a highly dispersion of active component. These results suggested that the distribution of Pt species on the support surface could be improved by adjusting photoreducation time and the longer time will be detrimental to the enhancement of $\mathrm{CO}$ oxidation activity.

\subsection{XPS analysis}

XPS analyses were carried out to determine the surface concentration and valence state of $\mathrm{Pt}$ in $\mathrm{Pt} / \mathrm{TiO}_{2}$ catalysts. The binding energies of Pt $4 f$ and the derived atomic contents in the different catalysts were summarized in Fig. 3 and Table 1. From Fig. 3 we found that the line shape and the width of $\operatorname{Pt}\left(4 f_{7 / 2}, 4 f_{5 / 2}\right)$ over the impregnated catalyst matched well with that of the metallic Pt. By comparison, the Pt $4 f$ features obtained from the photoreduced catalysts were quite broad, both zerovalence and cationic Pt could be found. According to previous reports, ${ }^{19,20}$ the Pt $4 f$ bands at $70.9 \mathrm{eV}$ could be related to metallic Pt, while those at $73.2 \mathrm{eV}$ could be assigned to $\mathrm{Pt}^{2+}$, respectively. Therefore, the relative atomic ratios of $[\mathrm{Pt}] /\left[\mathrm{Pt}^{2+}\right]$ decreased with the increase of photoreduction time. These results indicated that the valence state of Pt particles on the catalysts surface could be changed by adjusting photoreduction time. In addition, the atomic content on the support surface in the impregnated catalyst was much higher than those in the photoreduced catalysts, indicating that just partial Pt species could be deposited by photoreduction.

The XPS spectra of $\mathrm{TiO}_{2}$ were also detected in order to investigate the strong metal-support interaction (SMSI) for precious metal on reducible support. It is widely accepted that such ef-
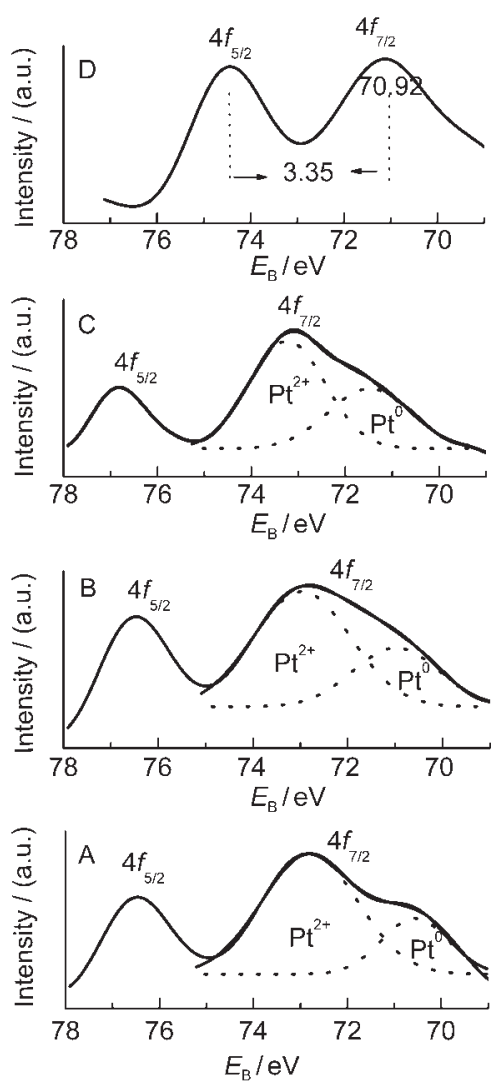

Fig.3 XPS spectra of $P t$ in various catalysts (A) $\mathrm{Pt} / \mathrm{TiO}_{2}$ (PR12), (B) $\mathrm{Pt} / \mathrm{TiO}_{2}$ (PR24), (C) $\mathrm{Pt} / \mathrm{TiO}_{2}$ (PR36), (D) $\mathrm{Pt} / \mathrm{TiO}_{2}$ (IM)

Table 1 XPS data of the catalysts $\mathrm{Pt} / \mathrm{TiO}_{2}(\mathrm{PR} 12), \mathrm{Pt} / \mathrm{TiO}_{2}$ (PR24), $\mathrm{Pt} / \mathrm{TiO}_{2}$ (PR36), and $\mathrm{Pt} / \mathrm{TiO}_{2}$ (IM)

\begin{tabular}{|c|c|c|c|c|c|c|}
\hline \multirow{2}{*}{ Catalyst } & \multicolumn{2}{|c|}{$E_{\mathrm{P} 44 / 7 / 2} / \mathrm{eV}$} & \multirow{2}{*}[\mathrm{Pt}]{$/\left[\mathrm{Pt}^{2+}\right]$} & \multirow{2}{*}[\mathrm{Pt}^{2+}]{} & \multirow{2}{*}[\mathrm{Pt}]{} & \multirow{2}{*}[\mathrm{Cl}]{} \\
\hline & $\mathrm{Pt}^{2+}$ & $\mathrm{Pt}$ & & & & \\
\hline PR12 & 72.8 & 70.5 & 3.12 & 0.053 & 0.017 & 1.5 \\
\hline PR24 & 73.0 & 71.0 & 2.20 & 0.048 & 0.022 & 0.7 \\
\hline PR36 & 73.2 & 71.5 & 1.70 & 0.044 & 0.026 & 0.4 \\
\hline IM & - & 70.9 & - & 0 & 0.31 & 1.2 \\
\hline
\end{tabular}

fects may be crucial in many aspects of heterogeneous catalysis. The binding energies of $\mathrm{TiO}_{2} 2 p$ in various $\mathrm{Pt} / \mathrm{TiO}_{2}$ catalysts were shown in Fig.4. From Fig.4(a) we can find that the line shape and the width of $\mathrm{TiO}_{2}\left(2 p_{3 / 2}, 2 p_{1 / 2}\right)$ over the impregnated catalyst matched well with those of the $\mathrm{Ti}^{4+}$, which indicated that $\mathrm{TiO}_{2}$ could not be reduced by $\mathrm{H}_{2}$ pretreatment. This result also suggested that there was a weak interaction between active center $\mathrm{Pt}$ and reducible support $\mathrm{TiO}_{2}$. However, the binding energies of $\mathrm{TiO}_{2}$ in photoreducted $\mathrm{Pt} / \mathrm{TiO}_{2}$ catalysts moved towards higher binding energy, maybe due to the production of part of $\mathrm{Ti}^{3+}$. According to previous report, ${ }^{21}$ the stoichiometric surface exists, in principle, as an oxygen vacancy and two $\mathrm{Ti}^{3+}$.

\subsection{Activity tests}

$\mathrm{CO}$ oxidation in the absence of hydrogen was carried out in a temperature region of $100-260{ }^{\circ} \mathrm{C}$ with a $\mathrm{CO} / \mathrm{O}_{2}$ molar ratio of 0.125 . For comparison, $\mathrm{CO}$ conversions over different catalysts versus reaction temperature were summarized in Fig.5. It can be found that the catalytic activities for $\mathrm{CO}$ oxidation are 


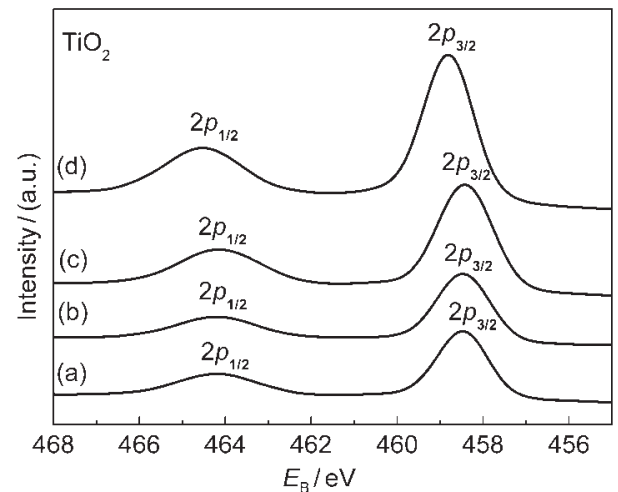

Fig.4 XPS spectra of $\mathrm{TiO}_{2}$ for various catalysts (a) $\mathrm{Pt} / \mathrm{TiO}_{2}$ (IM), (b) $\mathrm{Pt} / \mathrm{TiO}_{2}$ (PR12), (c) $\mathrm{Pt} / \mathrm{TiO}_{2}$ (PR24), (d) $\mathrm{Pt} / \mathrm{TiO}_{2}$ (PR36)

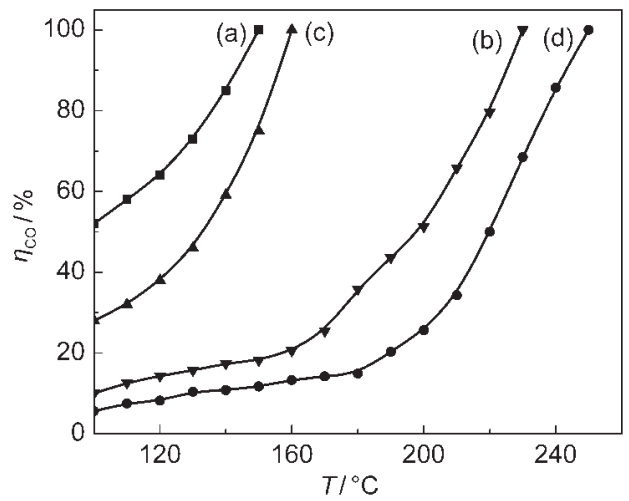

Fig.5 CO conversion vs reaction temperature over various catalysts

(a) $\mathrm{Pt} / \mathrm{TiO}_{2}$ (IM), (b) $\mathrm{Pt} / \mathrm{TiO}_{2}$ (PR12), (c) $\mathrm{Pt} / \mathrm{TiO}_{2}$ (PR24), (d) $\mathrm{Pt} / \mathrm{TiO}_{2}$ (PR36) very sensitive to preparation method. Performance of the impregnated catalyst is superior to those of photoreduced ones, which maybe due to the partial deposition of the Pt species resulted from photoreduction. Although both the nature of the active Pt phase and the elucidation of the mechanism for $\mathrm{CO}$ oxidation are still debated, herein, we consider that the Pt oxides are major active sites. Comparing the photoreduced catalysts, we found that their catalytic performance could be significantly promoted by adjusting the photoredution time. An optimum photoreduction time was $24 \mathrm{~h}$ and the longer time will be detrimental to the enhancement of $\mathrm{CO}$ oxidation activity. From Table 1 it can be found that the concentration of chlorine ions can be decreased from 1.5 to 0.4 when we increased photoreduction time from 12 to $36 \mathrm{~h}$. Whereas the excessive photoreduction can result in the aggregation of the Pt species as shown in XRD results above. This result is consistent with previous report. ${ }^{22}$ Therefore, the $\mathrm{Pt} / \mathrm{TiO}_{2}$ (PR24) catalyst exhibited the best activity for $\mathrm{CO}$ oxidation.

Furthermore, in order to investigate the effects of $\mathrm{H}_{2}$, a comparison of the catalytic activities for $\mathrm{CO}$ preferential oxidation in the presence of $\mathrm{H}_{2}$ between $\mathrm{Pt} / \mathrm{TiO}_{2}$ (IM) and $\mathrm{Pt} / \mathrm{TiO}_{2}(\mathrm{PR} 24)$ was made. The maximum $\mathrm{CO}$ conversions, the corresponding $\mathrm{O}_{2}$ conversions and selectivities of $\mathrm{CO}_{2}$ were shown in Fig.6. Our results showed that the maximum $\mathrm{CO}$ conversion of $61.4 \%$ on $\mathrm{Pt} / \mathrm{TiO}_{2}(\mathrm{PR} 24)$ was achieved at $180{ }^{\circ} \mathrm{C}$, the corre-

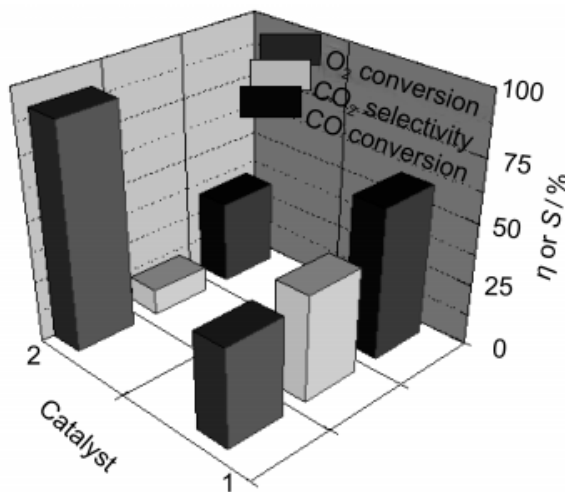

Fig.6 Activity comparison of the $\mathrm{CO}$ selective oxidation between $\mathrm{Pt} / \mathrm{TiO}_{2}$ (PR24) (1) and $\mathrm{Pt} / \mathrm{TiO}_{2}$ (IM) (2) catalysts

sponding $\mathrm{O}_{2}$ conversion and selectivity of $\mathrm{CO}_{2}$ were $40.0 \%$ and $43.0 \%$, respectively. However, the maximum $\mathrm{CO}$ conversion of $33.7 \%$ over the $\mathrm{Pt} / \mathrm{TiO}_{2}$ (IM) catalyst could not be obtained until the reaction temperature increased to $240{ }^{\circ} \mathrm{C}$. Furthermore, the higher $\mathrm{O}_{2}$ conversion of $91.4 \%$ resulted in a lower selectivity of $\mathrm{CO}_{2}$ of $11.2 \%$.

It has been reported that the electron transfer occurs between oxide support and $\mathrm{Au}$ nanoparticles or adsorbates, and influences the CO thermocatalytic oxidation. ${ }^{23-25}$ So, it can be proposed that the presence of $\mathrm{H}_{2}$ may also play a similar effect on the $\mathrm{CO}$ oxidation via electron transfer. These results indicate that the dissociative chemisorption $\mathrm{H}$ at surface oxygen vacancy sites of $\mathrm{TiO}_{2}$ deduced by photoreduction can act as both the electron-acceptors for the photogeneration electrons and the electron-donors for the chemisorbed $\mathrm{O}_{2}$ at $\mathrm{TiO}_{2}{ }^{26}$ We consider that a bi-function reaction mechanism maybe involved in $\mathrm{CO}$ preferential oxidation over the photoreduced $\mathrm{Pt} / \mathrm{TiO}_{2}$ catalysts, where $\mathrm{CO}$ adsorbs on the $\mathrm{Pt}$ species and $\mathrm{H}_{2}$ adsorbs at surface oxygen vacancy sites of $\mathrm{TiO}_{2}$. Therefore, the bi-function reaction mechanism weakens the competitive adsorption between $\mathrm{CO}$ and active oxygen on the Pt species, and subsequently enhances the activity for $\mathrm{CO}$ preferential oxidation in the presence of $\mathrm{H}_{2}$.

\section{Conclusions}

In summary, the photoreduction is an effective method to enhance the catalytic activity and selectivity of $\mathrm{CO}_{2}$ for the reaction of $\mathrm{PROX}$ in $\mathrm{H}_{2}$-rich stream. In photoreduction process, the dissociative chemisorption $\mathrm{H}$ at surface oxygen vacancy sites of $\mathrm{TiO}_{2}$ can act as the electron-donors for the chemisorbed $\mathrm{O}_{2}$ at $\mathrm{TiO}_{2}$, resulted in a bi-function reaction mechanism for $\mathrm{CO}$ preferential oxidation in $\mathrm{H}_{2}$-rich stream. In addition, a further research is in progress owing to the numerous influence factors on the photoreduction, such as the irradiate intensity, the $\mathrm{pH}$ value, and concentration of solution, etc.

\section{References}

(1) Du, W. P.; Li, Z.; Leng, W. H.; Xu, Y. M. Acta Phys.- Chim. Sin 2009, 25,1530 . [杜卫平, 李 臻, 冷文华, 许宜铭. 物理化学 
学报, 2009, 25, 1530. ]

(2) Liu, D.; Xu, Y. M. Acta Phys. -Chim. Sin. 2008, 24, 1584. [刘 鼎, 许宜铭. 物理化学学报, 2008, 24, 1584.]

(3) Wang, F.; Lu, G. X. Catal. Lett. 2007, 115, 46

(4) Wang, F.; Lu, G. X. Catal. Lett. 2010, 134, 72.

(5) Oh, S. H.; Sinkevitch, R. M. J. Catal. 1993, 142, 254.

(6) Kahlich, M. J.; Gasteiger, H. A.; Behm, R. J. J. Catal. 1997, $171,93$.

(7) Zkara, S. Ö.; Aksoylu, A. E. Appl. Catal. A-Gen. 2003, 251, 75.

(8) Geng, D. S.; Chen, L.; Lu, G. X. J. Mol. Catal. A 2007, 265, 42.

(9) Tang, Z. C.; Geng, D. S.; Lu, G. X. Thin Solid Films 2006, 497, 309.

(10) Wang, F.; Lu, G. X. J. Power Sources 2008, 181, 120.

(11) Wang, F.; Lu, G. X. Int. J. Hydrog. Energy 2010, 35, 7253.

(12) Wang, F.; Lu, G. X. J. Phys. Chem. C 2009, 113, 4161

(13) Wang, F.; Lu, G. X. J. Phys. Chem. C 2009, 113, 17070.

(14) Wang, F.; Lu, G. X. Chin. J. Catal. 2007, 28, 27. [王＼cjkstart芳, 吕 功煊. 催化学报, 2007, 28, 27.]

(15) Zhang, M.; Jin, Z. S.; Zhang, Z. J.; Dang, H. X. Appl. Surf. Sci. 2005, 250, 29.

(16) Zhang, M.; Jin, Z. S.; Zhang, Z. J.; Dang, H. X. J. Mol. Catal. A-Chem. 2005, 225, 59.
(17) Zhang, M.; Feng, C. X.; Jin, Z. S.; Chen, G.; Du, Z. L. Chin. J. Catal. 2005, 26, 508. [ 张敏, 冯彩霞, 金振声, 程 刚, 杜祖 亮. 催化学报, 2005, 26, 508.]

(18) Nishiyama, N.; Ichioka, K.; Park, D. H.; Egashira, Y.; Ueyama, K.; Gora, L.; Zhu, W. D.; Kapteijn, F.; Moulijn, J. Ind. Eng. Chem. Res. 2004, 43, 1211.

(19) Kim, K. S.; Winorgrad, N.; Davis, R. E. J. Am. Chem. Soc. 1971, 93, 6296

(20) Bornsten, L. In Zahlenwerte und Funktionen aus Naturwissenschaft und Technik; Springer: Berlin, 1982.

(21) Robert, G.; Peter, M.; Michael, B. Catal. Lett. 2004, 98, 129.

(22) Yang, J. C.; Kim, Y. C.; Shul, Y. G.; Shin, C. H.; Lee, T. K. Appl. Surf. Sci. 1997, 121, 525.

(23) Lopez, N.; Janssens, T. V. W.; Clausen, B. S.; Xu, Y.; Mavrikakis, M.; Bligaard, T.; Nǿskov, J. K. J. Catal. 2004, 223, 232.

(24) Giordano, L.; Goniakowski, J.; Pacchioni, G. Phys. Rev. B 2001, 64, 075417.

(25) Molina, L. M.; Hammer, B. Phys. Rev. Lett. 2003, 90, 206102.

(26) Dai, W. X.; Chen, X.; Wang, X. X.; Liu, P.; Li, D. Z.; Li, G. S.; Fu, X. Z. Phys. Chem. Chem. Phys. 2008, 10, 3256. 